\title{
PENINGKATAN HASIL BELAJAR PPKN MELALUI PENERAPAN MODEL PEMBELAJARAN KOOPERATIF TIPE STAD PADA KELAS IX.1 SMPN 1 KERUAK
}

\author{
Asri Nurhayani \\ SMP Negeri 1 Keruak \\ asrinurhayani.sh@gmail.com
}

\begin{abstract}
This study aims to determine the increase in PPKN learning outcomes through the application of the STAD type of cooperative learning model for class IX.I students of SMP Negeri 1 Keruak in 2019/2020 Academic Year. This Classroom Action Research is carried out by applying the STAD (Student Teams Achievement Divisions) Cooperative Learning Model in order to improve the quality of the learning process that helps teachers carry out PPKN learning activities tanght by means of maximizing the active role of students especially the knowledge they have and how they are applied in daily life-day. This Classroom Action Research (CAR) was conducted in 2 cycles, and the results of the actions that have been carried out are proven to be able to improve student achievement both in terms of completeness of student learning, namely in cycle I by 67\%, can be increased to $90 \%$ in cycle II or in terms of the average value of the evaluation results in the first cycle of 70.7 to 76.5 in the second cycle, this means there is an increase of 23\%. From the results of this classroom action research also showed an increase in the level of student learning activities from 2.83 Active Enough categories in the first cycle to 4.01 Active categories, meaning there was an increase of 1.18 .
\end{abstract}

Keywords: Learning Model, STAD Type, Learning Outcomes

\begin{abstract}
Abstrak : Penelitian ini bertujuan untuk mengetahui peningkatan hasil belajar PPKN melalui penerapan model pembelajaran kooperatif tipe STAD pada siswa kelas IX.I SMP Negeri 1 Keruak Tahun Pelajaran 2019/2020. Penelitian Tindakan Kelas ini dilakukan dengan menerapkan Model Pembelajaran Kooperatif Tipe STAD (Student Teams Achievement Divisions) dalam rangka meningkatkan kualitas proses pembelajaran yang membantu guru dalam melaksanakan kegiatan pembelajaran PPKN yang diajarkan dengan cara memakasimalkan peran aktif siswa terutama pengetahuan yang dimilikinya dan bagaimana penerapannya dalam kehidupan sehari-hari. Penelitian Tindakan Kelas ( PTK ) ini dilakukan dalam 2 siklus, dan dari hasil tindakan yang sudah dilakukan terbukti dapat meningkatkan prestasi belajar siswa baik dari segi ketuntasan belajar siswa yaitu pada siklus I sebesar 67\%, dapat meningkat menjadi $90 \%$ pada siklus II maupun dari segi nilai rata-rata hasil evaluasi yakni pada siklus I sebesar 70,7 menjadi 76,5 pada siklus II, ini berarti ada peningkatan sebesar $23 \%$.
\end{abstract}

As-Sabiqun : Jurnal Pendidikan Islam Anak Usia Dini

Volume 1, Nomor 2, Oktober 2019; 89-98

https://ejournal.stitpn.ac.id/index.php/assabiqun 
Dari hasil penelitian tindakan kelas ini juga menunjukkan adanya peningkatan tingkat aktivitas belajar siswa dari 2,83 kategori Cukup Aktif pada siklus I menjadi 4,01 kategori Aktif, berarti ada peningkatan sebesar 1,18.

Kata Kunci: Model Pembelajaran, Tipe STAD, Hasil Belajar

\section{PENDAHULUAN}

Pendidik yang profesional dapat terlihat dari keahliannya di dalam menyampaikan materi pembelajaran kepada peserta didik. Dalam menyampaikan materi yang efektif dan efisien, seorang pendidik perlu mengenal berbagai jenis metode pembelajaran sehingga dapat memilih metode yang paling tepat untuk mengajarkan suatu bidang studi tertentu yang tidak hanya berpikir tentang apa saja yang akan diajarkan, tetapi juga tentang siapa yang menerima pelajaran, apa makna dari belajar, dan bagaimana kemampuan dari peserta didik dalam mengikuti proses pembelajaran. ${ }^{1}$

Mata pelajaran PPKn merupakan mata pelajaran yang berhubungan dengan fenomena dalam persamaan kedudukan warga negara tanpa membedakan ras, agama, gender, golongan, budaya, dan suku, oleh karena itu siswa diharapkan melakukan pembelajaran yang kontekstual, melihat dari fenomena-fenomena yang dilakukan oleh masyarakat kemudian siswa diajak untuk melakukan atau membuat suatu pemecahan masalah yang terjadi di dalam masyarakat sekitar. Untuk mencapai tujuan PPKn tersebut, maka guru berupaya melalui kualitas pembelajaran yang dikelolanya, upaya ini bisa dicapai jika siswa mau belajar. Dalam belajar inilah guru berusaha mengarahkan dan membentuk sikap serta perilaku siswa sebagaimana yang dikehendaki dalam pembelajaran PPKn.

Student Teams Achievement Division (STAD) merupakan salah satu metode atau pendekatan dalam pembelajaran kooperatif yang sederhana dan merupakan suatu metode pembelajaran kooperatif yang efektif. Komponen STAD menurut Slavin adalah sebagai berikut: (1) Presentasi kelas. Presentasi kelas dalam STAD berbeda dari cara pengajaran yang biasa. Masing-masing kelompok mempresentasikan hasil diskusi kelompok mereka. Murid harus betul-betul

${ }^{1}$ Nur Jannah, E. (2019). Penerapan Metode Pembelajaran “Active Learning-Small Group Discussion” di Perguruan Tinggi Sebagai Upaya Peningkatan Proses Pembelajaran. FONDATIA, 3(2), 19-34. 
memperhatikan presentasi ini karena dalam presentasi terdapat materi yang dapat membantu untuk mengerjakan kuis yang diadakan setelah pembelajaran. (2) Belajar dalam tim. Murid dibagi menjadi beberapa kelompok, tiap kelompok terdiri dari 4-5 orang dimana mereka mengerjakan tugas yang diberikan. Jika ada kesulitan murid yang merasa mampu membantu murid yang kesulitan. (3) Tes individu yang dilaksanakan setelah pembelajaran. (4) Skor pengembangan individu. Skor yang didapatkan dari hasil tes selanjutnya dicatat oleh guru untuk dibandingkan dengan hasil prestasi sebelumnya. Skor tim diperoleh dengan menambahkan skor peningkatan semua anggota dalam 1 tim. Nilai rata-rata diperoleh dengan membagi jumlah skor penambahan dibagi jumlah anggota tim. (5) Penghargaan tim. Penghargaan didasarkan nilai rata-rata tim dimana dapat memotivasi mereka. ${ }^{2}$

Dalam melaksanakan proses pembelajaran pada mata pelajaran PPKN kelas IX.I SMP Negeri 1 Keruak ternyata penulis banyak menemukan permasalahan sehingga penulis mencoba menerapkan metode pembelajaran tipe STAD untuk meningkatkan hasil belajar PPKN siswa.

\section{METODE PENELITIAN}

Subyek penelitian adalah siswa kelas IX.I SMP Negeri 1 Keruak Kabupaten Lombok Timur tahun pelajaran 2019/2020 yang berjumlah 31 siswa dan terdiri atas 6 siswa laki-laki dan 25 siswa perempuan. Penelitian ini dilaksanakan di kelas IX.I SMP Negeri 1 Keruak yang merupakan tempat tugas peneliti. Penelitian ini dilaksanakan dengan menggunakan dua siklus. Penelitian ini dilaksanakan selama kurang lebih tiga bulan, yaitu mulai bulan Juli sampai dengan September 2019 .

Adapun yang menjadi indikator keberhasilan penelitian tindakan kelas ini adalah pencapaian prestasi anak dengan ketentuan sebagai berikut: Keberhasilan penelitian ini dilihat dari prestasi belajar mencapai ketuntasan klasikal yaitu jika 85\% anak mendapat skor minimal bintang 3 .

${ }^{2}$ Kristin, F. (2016). Efektivitas Model Pembelajaran Kooperatif Tipe STAD Ditinjau dari Hasil Belajar IPS Siswa Kelas 4 SD. Scholaria: Jurnal Pendidikan Dan Kebudayaan, 6(2), 74-79. 


\section{HASIL PENELITIAN DAN PEMBAHASAN}

Pada bagian ini peneliti akan mengemukakan analisis data yang diperoleh dari hasil observasi dan hasil evaluasi pada setiap siklus yang telah direncanakan. Data yang diperolah berupa data kuantitatif dari hasil evaluasi dan data kualitatif yang dikumpulkan dari hasil observasi. Data kuantitatif yang diperoleh dari hasil evaluasi akan memberikan jawaban mengenai keberhasilan atau tidaknya proses pembelajaran dengan menerapkan model pembelajaran kooperatif tipe STAD (Student Teams Achievement Divisions) yang diukur dengan ketuntasan belajar secara klasikal. Data kualitatif diperoleh dari hasil observasi yang akan memberikan gambaran tentang aktivitas siswa maupun aktivitas guru yang dilakukan oleh observer pada setiap pertemuan pelaksanaan proses pembelajaran. Berikut ini akan disajikan data hasil penelitian pada setiap siklus yang telah direncanakan.

Pada tahap ini yang akan dilakukan adalah kegiatan membuat rencana pelaksanaan pembelajaran, hasil evaluasi pada siklus I, hasil evaluasi pada siklus II, lembar observasi aktivitas siswa pada siklus I pertemuan 1, lembar observasi aktivitas guru pada siklus I pertemuan II, kisi-kisi soal evaluasi, Instrumen soal evaluasi, Kunci Jawaban, dan Pedoman Penskoran pada Siklus I, kisi-kisi soal evaluasi, Instrumen soal evaluasi, Kunci Jawaban, dan Pedoman Penskoran pada Siklus II.

Dalam tahap pelaksanaan tindakan dilaksanakan kegiatan pembelajaran sesuai dengan rencana pelaksanaan pembelajaran yang telah dibuat. Untuk dapat menyesuaikan rencana pelaksanaan pembelajaran dalam penyampaian materi, termasuk di dalamnya pembelajaran dengan menggunakan model pembelajaran kooperatif tipe STAD (Student Teams Acbievement Divisions) dilaksanakan dalam 3 kali pertemuan, dimana 2 kali pertemuan untuk penyampaian materi dan 1 kali pertemuan untuk evaluasi.

Hasil observasi diperoleh dari hasil pengamatan yang dilakukan oleh observer yang dilakukan oleh rekan guru peneliti dengan mengisi lembar observasi aktivitas guru dan aktivitas siswa untuk merekam jalannya proses pembelajaran. Dari hasil observasi dan pengamatan yang dilakukan, didapatkan bahwa proses pembelajaran belum sesuai dengan yang diharapkan karena masih terdapat kekurangan-kekurangan baik dari pihak guru sendiri maupun dari pihak siswa, antara lain; Guru belum memaksimalkan peran siswa dalam pembelajaran, masih ada siswa yang tidak aktif 
dalam kegiatan berdiskusi/mengerjakan tugas kelompok dari materi pelajaran yang dipelajari.

Berdasarkan hasil observasi terhadap aktivitas siswa setelah dianalisa diperoleh data sebagai berikut:

Tabel Hasil Observasi Aktivitas Siswa Pada Siklus I

\begin{tabular}{|c|c|c|c|c|c|c|c|c|c|}
\hline \multirow{2}{*}{ Pertemuan } & \multicolumn{6}{|c|}{ Jumlah skor yang tampak } & \multirow{2}{*}{$\begin{array}{l}\sum \text { Skor } \\
\text { aktivitas }\end{array}$} & \multirow{2}{*}{$\begin{array}{l}\text { Rata-rata } \\
\text { Aktivitas }\end{array}$} & \multirow{2}{*}{ Kategori } \\
\hline & 1 & 2 & 3 & 4 & 5 & 6 & & & \\
\hline Pertama & 3 & 2,33 & 3 & 2,33 & 1,7 & 2,7 & 15,06 & 2,51 & $\begin{array}{l}\text { Cukup } \\
\text { aktif }\end{array}$ \\
\hline Kedua & 3,7 & 3,33 & 3,7 & 2,7 & 2,7 & 2,7 & 18,83 & 3,14 & $\begin{array}{l}\text { Cukup } \\
\text { aktif }\end{array}$ \\
\hline
\end{tabular}

Dari tabel di atas dapat dilihat bahwa aktivitas belajar siswa pada siklus I pertemuan 1 adalah 2,51 dan pertemuan 2 adalah 3,14. Tingkat aktivitas siswa ini tergolong cukup aktif. Oleh karena itu maka aktivitas siswa pada siklus berikutnya masih perlu ditingkatkan.

Berdasarkan hasil observasi terhadap aktivitas guru setelah dianalisa diperoleh data sebagai berikut:

Tabel Hasil Observasi Aktivitas Guru Pada Siklus I

\begin{tabular}{|l|c|c|c|c|c|c|c|c|c|l|}
\hline \multirow{2}{*}{ Pertemuan } & \multicolumn{6}{|c|}{ Jumlah skor yang tampak } & E Skor & Rata-rata & \multirow{2}{*}{ Kategori } \\
\cline { 2 - 9 } & 1 & 2 & 3 & 4 & 5 & 6 & 7 & aktivitas & Aktivitas & \\
\hline Pertama & 2 & 2 & 3 & 2 & 2 & 2 & 2 & 15 & 2,14 & Baik \\
\hline Kedua & 3 & 2 & 3 & 2 & 3 & 2 & 3 & 18 & 2,57 & Baik \\
\hline
\end{tabular}

Dari tabel di atas dapat dilihat bahwa aktivitas guru pada siklus I pertemuan 1 adalah 2,14 dan pertemuan 2 adalah 2,57. Tingkat aktivitas guru ini tergolong baik. Oleh karena itu maka aktivitas guru pada siklus berikutnya masih perlu ditingkatkan.

Dari hasil analisis diketahui bahwa ketuntasan belajar yang dicapai siswa adalah 67\% dengan nilai rata-rata 70,7. Hasil ini belum mencapai ketuntasan belajar secara klasikal sehingga pembelajaran dilanjutkan ke siklus berikutnya. 
Berdasarkan analisis hasil observasi pada siklus I, jumlah siswa yang tuntas masih 74\% berarti masih di bawah standar minimum yakni $85 \%$. Hasil tersebut belum mencapai hasil yang diharapkan. Untuk itu peneliti melanjutkan ke siklus berikutnya. Dalam siklus I ini terdapat kekurangan-kekurangan yang perlu untuk dipehatikan dan diperbaiki pada kegiatan siklus II, di antaranya:

1. Pemberian motivasi dan apersepsi yang masih kurang membuat siswa sedikit kebingungan dalam menerima materi atau pokok bahasan baru dengan menerapkan pembelajaran kooperatif teknik STAD (Student Teams Achievement Divisions) sehingga pada siklus II pemberian motivasi dan apersepsi lebih diperhatikan.

2. Meminta siswa untuk lebih aktif dalam berdiskusi, (tidak hanya diam memperhatikan teman-temannya bekerja dan hanya mengobrol dengan temannya.

3. Meminta siswa agar lebih aktif dan bertanya jika mendapat kesulitan atau jika ada materi dan soal-soal diskusi yang belum dimengerti.

4. Kesimpulan yang belum jelas membuat siswa sedikit bingung atau kurang jelas dengan batasan materi yang disampaikan guru sehingga pada siklus II pemberian kesimpulan lebih diperhatikan.

Proses pembelajaran pada siklus II diawali dengan pemberian umpan balik dari hasil evaluasi yang diberikan. Oleh karena itu, sebelum berdiskusi guru menghimbau agar siswa tidak ada yang ngobrol, mengganggu temannya yang lain, dan tidak ada siswa yang diam memperhatikan teman-temannya, demikian juga pembagian tugas dalam setiap kelompok harus lebih jelas sehingga siswa dapat melaksanakan tugasnya masing-masing.

Pada tahap ini yang akan dilakukan adalah kegiatan membuat rencana pelaksanaan pembelajaran, lembar observasi aktivitas guru pada siklus II pertemuan 1, lembar observasi aktivitas guru pada siklus II pertemuan 2, lembar observasi aktivitas siswa pada siklus II pertemuan 1, dan lembar observasi aktivitas siswa pada siklus II pertemuan 2, kisi-kisi soal evaluasi siklus II, instrumen evaluasi siklus II, kunci jawaban instrumen evaluasi dan pedoman penskoran, hasil evaluasi siklus II. 
Dalam tahap pelaksanaan tindakan dilaksanakan kegiatan pembelajaran sesuai dengan rencana pelaksanaan pembelajaran yang telah dibuat. Untuk dapat menyesuaikan rencana pelaksanaan pembelajaran dalam penyampaian materi, termasuk didalamnya pembelajaran dengan menggunakan model pembelajaran kooperatif tipe STAD (Student Teams Achievement Divisions) dilaksanakan dalam 3 kali pertemuan, dimana 2 kali pertemuan untuk penyampaian materi dan 1 kali pertemuan untuk evaluasi.

Hasil observasi diperoleh dari hasil pengamatan yang dilakukan oleh observer yang dilakukan oleh rekan guru peneliti dengan mengisi lembar observasi aktivitas guru dan aktivitas siswa untuk merekam jalannya proses pembelajaran. Pada saat pembelajaran siklus II telah dilakukan perbaikan, dari analisis hasil observasi aktivitas siswa pada siklus II didapat bahwa aktivitas siswa tergolong aktif dalam setiap pertemuan. Hal ini dapat dilihat pada tabel skor aktivitas siswa mengalami peningkatan dari pertemuan pertama ke pertemuan ke dua, seperti yang terlihat pada tabel dibawah ini.

Tabel Hasil Observasi Aktivitas Siswa Pada Siklus II

\begin{tabular}{|c|c|c|c|c|c|c|c|c|c|}
\hline \multirow{2}{*}{ Pertemuan } & \multicolumn{6}{|c|}{ Jumlah skor yang tampak } & \multirow{2}{*}{$\begin{array}{l}\sum \text { Skor } \\
\text { aktivitas }\end{array}$} & \multirow{2}{*}{$\begin{array}{l}\text { Rata-rata } \\
\text { Aktivitas }\end{array}$} & \multirow{2}{*}{ Kategori } \\
\hline & 1 & 2 & 3 & 4 & 5 & 6 & & & \\
\hline Pertama & 4 & 4 & 4 & 3,33 & 3,7 & 3,33 & 22,36 & 3,73 & Aktif \\
\hline Kedua & 4,7 & 4,33 & 4,7 & 3,7 & 4,33 & 4 & 25,76 & 4,29 & Aktif \\
\hline
\end{tabular}

Dari tabel di atas dilihat bahwa aktivitas siswa pada siklus II untuk pertemuan 1 adalah 3,73 dan pertemuan 2 adalah 4,29. Berdasarkan penggolongan aktivitas belajar siswa maka kategori aktivitas siswa pada siklus II adalah tergolong aktif.

Sedangkan menyangkut aktivitas guru dalam kegiatan pembelajaran dapat dilihat pada tabel di bawah ini.

\section{Tabel Hasil Observasi Aktivitas Guru Pada Siklus II}

\begin{tabular}{|l|c|c|c|c|c|c|c|c|c|l|}
\hline \multirow{2}{*}{ Pertemuan } & \multicolumn{6}{|c|}{ Jumlah skor yang tampak } & \multirow{2}{*}{$\begin{array}{c}\text { S Skor } \\
\text { aktivitas }\end{array}$} & $\begin{array}{c}\text { Rata-rata } \\
\text { Aktivitas }\end{array}$ & Kategori \\
\cline { 2 - 8 } & 1 & 2 & 3 & 4 & 5 & 6 & 7 & 20 & 2,86 & Baik \\
\hline Pertama & 3 & 2 & 4 & 3 & 3 & 3 & 2 & 20 & 3,43 & $\begin{array}{l}\text { Baik } \\
\text { sekali }\end{array}$ \\
\hline Kedua & 4 & 4 & 4 & 3 & 3 & 3 & 3 & 24 & & \\
\hline
\end{tabular}


Dari tabel di atas dilihat bahwa aktivitas guru pada siklus II untuk pertemuan 1 adalah 2,86 dengan kategori baik dan pertemuan 2 adalah 3,43 dengan kategori baik sekali. Berdasarkan penggolongan aktivitas belajar guru maka kategori aktivitas guru pada siklus II adalah tergolong baik sekali.

Hasil evaluasi yang diperoleh pada siklus II ini mencapai tingkat 90\% jadi sudah dapat dikatakan tuntas, untuk itu tidak perlu lagi diadakan pembelajaran pada siklus berikutnya dengan ketuntasan belajar yang sudah dicapai, dengan demikian pembelajaran dengan menerapkan model pembelajaran kooperatif tipe STAD (Student Teams Achievement Divisions) dikatakan dapat meningkatkan hasil belajar PPKn.

Dari hasil observasi aktivitas siswa pada siklus II, kegiatan pembelajaran sudah dapat berjalan dengan baik, di mana hasil observasi aktivitas siswa dapat tergolong aktif dilihat dari setiap kegiatan pembelajaran begitu juga aktivitas guru sudah tergolong baik sekali. Dari hasil analisis terhadap hasil evaluasinya terjadi peningkatan rata-rata kelas maupun persentase ketuntasan secara klasikal sudah mencapai/melebihi $85 \%$ artinya sudah $85 \%$ atau lebih siswa sudah mencapai nilai hasil ulangan sebesar KKM atau melebihi KKM yang ditentukan. Oleh karena itu penelitian ini dihentikan sampai siklus II sesuai dengan perencanaan.

Penelitian tindakan kelas ini dilaksanakan sebagai upaya untuk meningkatkan hasil belajar mata pelajaran PPKn pada siswa kelas IX.I Semester I dengan melaksanakan pembelajaran dengan menerapkan/menggunakan model pembelajaran kooperatif tipe STAD (Student Teams Achievement Divisions) di SMP Negeri 1 Keruak Kabupaten Lombok Timur Tahun Pelajaran 2019/2020.

Berdasarkan hasil analisis data pada tiap siklus, terlihat bahwa hasil dari siklus I ke siklus II mengalami peningkatan. Pada pelaksanaan pembelajaran dan hasil analisis data siklus I, untuk aktivitas siswa diperoleh nilai rata-rata sebesar 2,83 dan aktivitas siswa pada siklus II diperoleh nilai rata-rata kelas sebesar 4,01. Pada pelaksanaan pembelajaran dan hasil analisis data siklus I, untuk aktivitas guru diperoleh nilai rata-rata sebesar 2,36 dan aktivitas guru pada siklus II diperoleh nilai rata-rata sebesar 3,15. 
Terkait dengan hasil ulangan pada siklus I dan II dapat dilihat rinciannya dibawah ini.

Tabel Ringkasan Hasil Evaluasi Pada Siklus I

\begin{tabular}{|l|l|c|}
\hline No. & \multicolumn{1}{|c|}{ Uraian } & Hasil \\
\hline 1 & Nilai Terendah & 60 \\
\hline 2 & Nilai Tertinggi & 85 \\
\hline 3 & Rata-rata & 70,7 \\
\hline 4 & Jumlah siswa yang tuntas & 20 \\
\hline 5 & Jumlah siswa yang ikut tes & 30 \\
\hline 6 & Persentase yang tuntas & $67 \%$ \\
\hline
\end{tabular}

Sedangkan pada siklus II hasilnya sebagai berikut.

Tabel Ringkasan Hasil Evaluasi Pada Siklus II

\begin{tabular}{|l|l|c|}
\hline No. & \multicolumn{1}{|c|}{ Uraian } & Hasil \\
\hline 1 & Skor Terendah & 60 \\
\hline 2 & Skor Tertinggi & 90 \\
\hline 3 & Rata-rata & 76,5 \\
\hline 4 & Jumlah siswa yang tuntas & 27 \\
\hline 5 & Jumlah siswa yang ikut tes & 30 \\
\hline 6 & Persentase yang tuntas & $90 \%$ \\
\hline
\end{tabular}

Setelah melihat kedua tabel hasil evaluasi dari siklus I dan II di mana nilai yang mereka peroleh sudah mencapai tingkat ketuntasan belajar dan melebihi tingkat ketuntasan belajar secara klasikal yaitu 85\%.

Penelitian tindakan kelas ini dilaksanaan sebagai upaya untuk meningkatkan aktivitas dan hasil belajar mata pelajaran PPKn melalui penerapan model pembelajaran kooperatif tipe STAD (Student Teams Achievement Divisions). 


\section{KESIMPULAN}

Dari hasil penelitian dan pembahasan di atas dapatlah kami simpulkan sebagai berikut:

1. Penerapan model pembelajaran kooperatif tipe STAD (Student Teams Achievement Divisions) dapat meningkatkan hasil belajar PPKn pada siswa kelas IX.I SMP Negeri 1 Keruak Tahun Pelajaran 2019/2020.

2. Penerapan model pembelajaran kooperatif tipe STAD (Student Teams Achievement Divisions) dapat meningkatkan aktivitas belajar para siswa pada mata pelajaran PPKn pada siswa kelas IX.I SMP Negeri 1 Keruak Tahun Pelajaran 2019/2020 yang dapat dilihat dari peningkatan aktivitas belajar dari siklus I sampai dengan siklus II, dari kategori cukup aktif dengan nilai rata-rata 2,83 sampai dengan kategori aktif dengan nilai rata-rata 4,01.

3. Hasil belajar siswa pada mata pelajaran PPKn kelas IX.I di SMP Negeri 1 Keruak Tahun Pelajaran 2019/2020 mengalami peningkatan pada setiap siklus dengan persentase ketuntasan secara klasikal masing-masing siklus yaitu siklus I sebesar $67 \%$ dan siklus II sebesar 90\% berarti ada kenaikan $23 \%$.

\section{DAFTAR PUSTAKA}

Anita Lie, 2008. Cooperative Learning. Jakarta : PT Gramedia.

Kristin, F. (2016). Efektivitas Model Pembelajaran Kooperatif Tipe STAD Ditinjau dari Hasil Belajar IPS Siswa Kelas 4 SD. Scholaria: Jurnal Pendidikan Dan Kebudayaan, 6(2), 74-79.

Nur Jannah, E. (2019). Penerapan Metode Pembelajaran “Active Learning-Small Group Discussion” di Perguruan Tinggi Sebagai Upaya Peningkatan Proses Pembelajaran. $\quad$ FONDATIA, 3(2), 19-34. https://doi.org/10.36088/fondatia.v3i2.219

Oemar Hamalik, 2008. Proses Belajar Mengajar. Jakarta : Bumi Aksara. Roestiyah N.K, 2008. Strategi Belajar Mengajar. Jakarta : Rineka Cipta.

Slameto, 2003. Belajar dan Faktor-Faktor yang Mempengarubinya. Jakarta : Rineka Cipta Suharsimi Arikunto, dkk. 2008. Penelitian Tindakan Kelas. Jakarta : Bumi Aksara. Suprijono Agus, 2009. Cooperative Learning. Yogyakarta : Pustaka Pelajar. Syaiful Bahri Djamarah, 1994. Prestasi Belajar dan Kompetensi Guru. Surabaya: Usana Offset Printing. 